\title{
Nursing Modality Therapy (Spiritual Deep Breathing) Resolve Student Distress
}

\author{
Kushariyadi, Grysha Viofananda Kharsima Ade Agung, Faizatul Mazuin, Fitriany \\ Faculty of Nursing Universitas Jember, Jember Indonesia \\ Correspondingemail: kushariyadi@unej.ac.id
}

Submitted: 24-08-2018 Accepted: 02-09-2019 Published: 05-12-2019

\begin{abstract}
The condition of nursing faculty students has many academic tasks such as attending classes, taking exams, socializing, adjusting to fellow students with different characteristics and backgrounds, developing talents and interests through non-academic activities. This condition causes students to not be able to manage time well so that they experience distress. Quasy experiment research used two groups pre-post-test design. The sample included 15 control groups and 15 treatment groups. The sampling technique uses simple random sampling. Research variables include spiritual deep breathing therapy and distress rate. The instrument uses depression anxiety stress scale-42 (DASS-42) in the form of a Likert scale. This type of unfavorable questionnaire contains 42 questions. The spiritual instrument deep breathing therapy is about 20 minutes a day for seven days. Statistical test using Wilcoxon signed rank test against both groups. There was a significant effect on the treatment group (p-value 0.001 ). In the control group there was no effect ( $p$-value 0.263 ). Distress conditions in a person can be overcome with one therapy such as spiritual deep breathing therapy. Spiritual deep breathing therapy as a therapy for nursing modalities can optimize oxygen demand for cells that are distressed, blood flow to the muscles decreases otherwise blood flows to the brain and skin increases so as to provide a sense of warmth, comfort and calm.
\end{abstract}

Keywords: Distress, nursing modality therapy, spiritual deep breathing therapy. 
Kushariyadi: Nursing Modality Therapy (Spiritual Deep Breathing) Resolve Student Distress

\section{Introduction}

The condition of students Faculty of Nursing, University of Jember have the academic demands such as attending class, obeying the exam, socialize, adapt to the characteristics and fellow students of different backgrounds, develop their talents and interests through non-academic activities. Students cannot manage time well so experiencing distress.

The prevalence of distress in students in North America by 100 respondents (38\%) (Shannone, 1999). The prevalence of distress in students in the UK as many as 165 respondents $(31.2 \%)$ (Firth, 2004). The prevalence of distress in students in India as much as 180 respondents (34\%) (Kumar, 2011). The prevalence of distress in students in Saudi Arabia of 494 respondents (57\%) and in Malaysia as many as 396 respondents (41.9\%) (Sherina, 2004). The prevalence of distress in students in Indonesia in University of Jember Health Services Unit as many as 79 respondents (75.9\%) (Wahyuni, 2015). The prevalence of distress at Faculty of Medicine University of Jember students categorized as moderate stress were 107 respondents (57\%) (Evanda et al., 2014).

The cause of distress among other demands of academic life, social, and personal (Dyrbye et al., 2006 in Jaisoorya et al., 2017). Lots of activities and tasks, environmental changes, loss of social support, academic pressure, relationships with peers, and financial problems into soulmate factor causes distress (Azzahra, 2017). The bad interpersonal relationship is the most common stress factors (Hashimoto, 2012). Factors that cause stress, according to research Saam (2006) of the Faculty of Medicine students of Riau are personal factors, family, school, and community. Personal factors include the inability to set the time, the monthly money runs out, exhausting themselves to study, friends are too often comes to renting, pain does not go away, trouble with friends, mood changes frequently, breakup, lack of affection from a lover, and breakup. Family factors include parents divorced, unfettered, parents quarreling, lack of affection and parents do not meet the wishes of children. Factors include the campus and piling too many tasks, to study for a full day, yet have lecture materials, problems with teachers, professors do not understand the explanation, a full exam for one week. Community factors include isolation, protests or criticism, receive discrimination and bullying, the environment is not conducive.

Impact distress resulting in decreased concentration and school performance because burdened by campus and social life. Interpersonal stressful experiences lead to serious problems. Mental health problems like depression and anxiety cause stress interpersonal (Hashimoto, 2012). Severe distress cause auditory hallucinations that disrupt the central nervous system, stimulates the negative voices even endanger yourself and others (Ellet, 2017). Distress detrimental impact on physical and mental health cause spiritual distress individuals and families (Dewi, 2014). Decreasing the concentration of student learning therefore burdened campus and social life, as well as poor social interpersonal relationships. Another impact of distress such as hypovolemic shock, impaired tissue perfusion, energy use disorders, delayed wound healing, and the rate of metabolism disorders (Winkler et al., 2008).

One solution is to give students overcome distress spiritual deep breathing therapy. Therapy appropriately and regularly can give maximum results. Application of nursing modality therapy is useful for improving the quality of life and improve health (Sepdianto, 2008).

\section{Method}

The study was quasi-experiment using two group pre-posttest design. The study aims to determine the distress of students before and after giving nursing modality therapy spiritual deep breathing. Measuring the level of distress (pretest) in the treatment and control group respondents then provide intervention spiritual deep breathing therapy and remeasure the level of distress (posttest) in the treatment and control group respondents.

Total sample each treatment group and control as many as 15 respondents. The research using simple random sampling techniques. Inclusion criteria include: 1) 
Kushariyadi: Nursing Modality Therapy (Spiritual Deep Breathing) Resolve Student Distress

gender to male and female; 2) aged 18-21 years; 3) co-operative; 4) willing to become respondents; 5) actively enter the class; 6) can be measured stress level.

Place of research at the Faculty of Nursing, University of Jember August 2017.

The study used an instrument nursing modality therapy spiritual deep breathing. Adopting and modifying of research Benson (1974), entitled "your innate assets for combating stress" with spiritual therapy. This technique can relieve pain, insomnia, anxiety, and stress. Implementation of the therapy duration of 20 minutes per day for seven days.

Instruments distress using a questionnaire depression anxiety stress scale-42 (DASS42) and has received permission from the author. The DASS-42 questionnaire is adapted from Matthews (2016), entitled "distress". Scale questionnaire Likert scale. Question unfavorable types. amounted to 42 of the questions. Rate each question: 1) value of 0 (no or never); 2) the value of (according to experienced up to a certain level, or sometimes); 3) value of 2 (common); 4) value of 3 (very appropriate with experienced, or almost all the time). The final assessment: 1) the value $0-14$ (normal); 2) value of 15 18 (mild stress); 3 ) value of 19-25 (moderate stress); 4) value of 26-33 (stress); and 5) the value of $\geq 34$ (very severe stress).

Data collection and processing stages include: 1) conduct research and fill permit informed consent as a sign of willingness; 2) measuring the level of distress (pre-test) on the first day; 3 ) provide nursing intervention modality therapy spiritual deep breathing for 20 minutes on the first day until the seventh; 4) measuring the level of distress (posttest) after administration of nursing modalities therapy spiritual deep breathing on the seventh day; 5) analyze the research data using the Wilcoxon signed rank test with $p$ $<0.05$ towards treatment groups and control groups (Nursalam, 2008).

This study applies the ethics of research include: 1) research consent form; 2) anonymous; 3) safety and comfort; 4) confidentiality; 7) justice (Potter \& Perry, 2006).

\section{Results}

Table 1 Characteristics of Respondents Based on Gender, Age and Heart Rate

\begin{tabular}{|c|c|c|c|c|c|}
\hline \multirow[t]{2}{*}{ No } & \multirow{2}{*}{$\begin{array}{c}\text { Respondent } \\
\text { Characteristics }\end{array}$} & \multicolumn{2}{|c|}{ Treatment } & \multicolumn{2}{|c|}{ Controls } \\
\hline & & $\mathbf{f}$ & $\%$ & f & $\%$ \\
\hline \multirow[t]{3}{*}{1} & Gender & & & & \\
\hline & Female & 8 & 53.33 & 7 & 46.67 \\
\hline & Male & 7 & 46.67 & 8 & 53.33 \\
\hline \multirow[t]{3}{*}{2} & Age & & & & \\
\hline & Young & 10 & 66.66 & 12 & 80 \\
\hline & Adults & 5 & 33.33 & 3 & 20 \\
\hline \multirow[t]{11}{*}{3} & Vital signs & & & & \\
\hline & 1. Blood Pressure & & & & \\
\hline & Normal & 15 & 100 & 15 & 100 \\
\hline & Hypotension & 0 & 0 & 0 & 0 \\
\hline & Hypertension & 0 & 0 & 0 & 0 \\
\hline & 2. Heart Rate & & & & \\
\hline & Normal & 15 & 100 & 15 & 100 \\
\hline & Tachycardia & 0 & 0 & 0 & 0 \\
\hline & Bradycardia & 0 & 0 & 0 & 0 \\
\hline & 3. Respiratory Rate & & & & \\
\hline & Normal & 13 & 86.67 & 14 & 93.33 \\
\hline
\end{tabular}

Volume 7 Issue 3 December 2019 
Kushariyadi: Nursing Modality Therapy (Spiritual Deep Breathing) Resolve Student Distress

$\begin{array}{ccccc}\text { Tachypnea } & 2 & 13.33 & 1 & 6.67 \\ \text { Bradypnea } & 0 & 0 & 0 & 0 \\ \text { 4. Temperature } & & 66.67 & 14 & 93.33 \\ \text { Normal } & 10 & 20 & 0 & 0 \\ \text { Hyperthermia } & 3 & 13.33 & 1 & 6.67 \\ \text { Hypothermia } & 2 & \end{array}$

Test Results Wilcoxon Signed Rank Test

Table 2 Results of Wilcoxon Signed Rank Test in Treatment Group

\begin{tabular}{ccccc}
\hline Category & $\mathbf{n}$ & $\begin{array}{c}\text { Median } \\
(\text { min-max })\end{array}$ & mean \pm SD & p \\
\hline Distress before the intervention & 15 & $15(7-27)$ & $4.998 \pm 15.53$ & 0.001 \\
Distress after intervention & 15 & $6(4-14)$ & $6.53 \pm 2.850$ & \\
\hline
\end{tabular}

Table 3 Results of Wilcoxon Signed Rank Test in Control Group

\begin{tabular}{ccccc}
\hline Category & $\mathbf{n}$ & $\begin{array}{c}\text { Median } \\
(\mathbf{m i n}-\mathbf{m a x})\end{array}$ & mean \pm SD & p \\
\hline Distress as a pre-test & 15 & $13(3-26)$ & $6.307 \pm 13.07$ & 0.263 \\
Distress when the post-test & 15 & $15(5-23)$ & $13.87 \pm 5.330$ & \\
\hline
\end{tabular}

Table 4 Results of Mann Withney U Test

\begin{tabular}{cccc}
\hline Category & $\mathbf{n}$ & $\begin{array}{c}\text { Median } \\
(\text { min-max })\end{array}$ & $\mathbf{p}$ \\
\hline Control Group & 15 & $8(3-26)$ & 0.001 \\
Treatment Group & 15 & $15(8-23)$ & \\
\hline
\end{tabular}

\section{Characteristics of Respondents}

Table 2 shows the mean of 15.53 distress before the intervention and after intervention by 6.53 . The mean distress declined by 9.00 . Results of the Wilcoxon test showed $p=0.001$ $(p<0.05)$ means that there is a significant difference between prior to giving spiritual deep breathing therapy and after being given spiritual deep breathing therapy.

Table 3 shows the mean of distress as a pre-test of 13.07 and the current post-test of 13.87. The mean distress increased by 0.8 . Results of the Wilcoxon test showed $\mathrm{p}=0.263$ $(p>0.05)$ means that there is no significant difference between the current pre-test to post-test time.

Table 4 shows results of Mann whitney statistical test between post treatment group and post control group showed $\rho=$ 0.001 because the value of $\rho<0.05$, it was concluded that there was a difference in the administration of spiritual deep breathing therapy between treatment and control groups.

\section{Discussion}

\section{Distress in Treatment Group}

Table 2 shows a significant difference $(p=0.001)$ were significant distress among college students before and after giving of spiritual deep breathing therapy. Looked at the results of the average value of student distress before giving treatment 15.53. After giving treatment mean value of student distress becomes 6.53. There is a decrease in mean values distress difference between pretest and post-test of 9.00. This means giving spiritual deep breathing therapy effect on student distress. 
Kushariyadi: Nursing Modality Therapy (Spiritual Deep Breathing) Resolve Student Distress

Research in the Southern Illinois University School of Medicine, the USA in 2004-2006 proved that distress affects the performance of students from both academic and nonacademic. Giving techniques stress reduction regularly and consistently to students in some medical schools can help overcome academic problems due to stress. The results of the study reported that the perception of anxiety, nervousness, doubt, and loss of concentration was decreased (Paul, 2007).

Research in Japan proves the use of techniques deep breath as a method to reduce tension and improve mood. Another method uses relaxation techniques of yoga and progressive muscle relaxation (Hayama, 2012).

Nurhadi \& Nursalam study (2003) that the spiritual guidance of a positive impact on stress reduction clients who are hospitalized and clients with a terminal illness. Stress reduction impact on increasing the immune response so that clients can minimize secondary infections.

Research Valentina (2016) that there are significant deep breathing relaxation techniques with improved mood thereby reducing the level of stress in terms of evaluation self-reported as well as heart rate and salivary cortisol levels.

Harris Research \& Coy (2003) that students can use breathing relaxation techniques to calm down during the exam. Students who meditate use breathing relaxation techniques showed significant improvement in academic achievement. Research Adams (2004) that the relaxation techniques helpful respiratory symptoms ward or response light flight associated with anxiety and distress include increased heart rate, respiration, blood pressure, muscle tension, and discomfort.

Use of the effect of relaxation therapy trivial but with the advantages of the technique that is fast, simple and involves minimal resources into appropriate solutions in all circles. Research shows this therapy is easy to learn $(<10$ minutes) and effectively used by all ages, especially children 5 years old. This therapy is easier to apply than the antistress therapy techniques others although the main obstacle is the inability flew children's describing health problems (Valentina, P., \& Blandini, M. (2016).
Respiratory effects in the student sample show taking deep breaths can help reduce feelings of anxiety and stress, improve performance and concentration. Deep breathing can also reduce some symptoms of Parkinson's disease, epilepsy, posttraumatic stress disorder (PTSD), depression, hypertension and other chronic diseases. Breathing in is also useful as a simple motor skills disabilities rehabilitation (Valentina, 2016).

Based on the data characteristics of the respondents (pulse) that takes 10-20 minutes a day to achieve relaxation against stress. It is important in the relaxation program are 1) the repetition of a word, sound, prayer, thought, phrase or muscle movements; 2) re-focus and concentrate to repeat when the mind is disturbed. Evidently, if the pulse becomes stable because exfluks $\mathrm{Ca} 2$ + which make increased vascular permeability that gives the effect of comfortable, relaxed, and calm.

Data characteristics of the respondents (respiratory rate) that appear regular or irregular rhythm in the treatment group. This suggests that there is feedback response in the hypothalamus secrete ACTH which will lower cortisol production, thereby reducing the striated muscle contraction lungs that provide the quiet and comfortable effect.

\section{Conclusion}

There is a decrease in distress before and after nursing modalities therapy spiritual deep breathing in the treatment group. No decrease in distress as a pre-test and post-test in the control group.

Nursing modalities therapy spiritual deep breathing is a technique that combines a breath in the spiritual aspect of the method that begins the prayer so as to calm the mind and have a positive impact and a sense of comfort to the body cope with stress. The benefits of deep breathing spiritual therapy is indeed not directly felt in all therapy but it should be continued so that it will provide a fresh effect, comfortable, relaxed in students so that they can improve learning achievement. Need the active participation of students to use these therapies independently so that decrease stress levels are visible. 
Kushariyadi: Nursing Modality Therapy (Spiritual Deep Breathing) Resolve Student Distress

\section{References}

Adams, J. (2004). Straining to describe and tackle stress in medical students. US National Of Medicine: Medical Education, 38, 46-64. doi: $\quad 10.1111 / \mathrm{j} .1365-2929.2004 .01810 . x$. https://www.ncbi.nlm.nih.gov/pubm ed /24,904,226.

Azzahra, F. (2017). Effect of resilience against psychological distress in mahasiswa. Jurnal Scientific Psychology, 5(01), 80-81. http://ejournal.umm.ac.id/index.php/jipt/ article/view/3883/4336.

Benson, H. M. D., Greenwood, M. M., \& Klemchuk, H. (1974). The Relaxation Response: Psychophysiologic Aspects and Clinical Applications. The International Journal of Psychiatry in Medicine. Sage Journals, 1, March 1, 1975. https://doi. org/10.2190/376W-E4MT-QM6Q-HOUM.

Dewi, S. (2014). Gerontik Nursing Textbook. Issue 1. Yogyakarta: Lee publish.

Ellet, L., Luzon, O., \& Abbas, Z. (2017). Distress, omnipotence, and responsibility beliefs in command hallucinations. British Journal of Clinical Psychology, 56(3), 1-7. doi: 10.1111/bjc.12139. https://www.ncbi. nlm.nih.gov/pubmed/28493561.

Evanda, B., Alif, M., \& Rony, P. (2014). Factors affecting internal stress on the student force Jember University School of Medicine in 2014. Faculty of Medicine: University of Jember.

Firth, L. D. J., Mellor, K. A., Moore, C., \& Loquet. (2004). How managers can reduce employee intention to quit?. Journal of Managerial Psychology, 19 (2), 17-187. www.emeraldinsight.com.

Harris, H. L., \& Coy, D. R. (2003). Helping students cope with test anxiety. ERIC Digest (ED479355). Taken from storage http:// eric.ed.gov/ERICDocs/data/ericdocs2/ content $01 / 0000000 \mathrm{~b} / 80 / 2 \mathrm{a} / 3 \mathrm{a} / 0 \mathrm{c} . p d f$.

Hashimoto, T., Mojaverian, T., \& Kim, H. S. (2012). Culture, interpersonal stress, and psychological distress. Journal of CrossCultural Psychology, 43(4), 527-532. doi: 10.1177/0022022112438396. http://journals. sagepub.com/.

Hayama, H. R., Vilberg, K. L., \& Ruqq, M. D. (2012). Overlap between the neural correlates of cued recall and source memory: evidence for a generic recollection network?. J Coqn Neurosci. 2012 May, 24(5): 1127-37. doi: 10.1162/jocn_a_00202. Epub 2012 Jan 30 .

Jaisoorya, T. S., Rani,A., Menon, P. G., Jeevan, C. R., Revamma, M., Jose, V., Radhakrishnan, K. S., Kishore, A., Thennarasu, K., \& Nair, S. (2017). Psychological distress among college student in Kerala, India-prevalence, and Correlates. Asian Journal of Psychiatry, 28, 28-31. doi: 10.1016/j.ajp.2017.03.026. www.sciencedirect.com.

Kumar, A. A., Karthick, K. A., \& Rumugam, K. P. (2011). Properties of Biodegradable Polymers and Degradatin for Sustainable Development. International Journal Of Chemical Engineering and Applications, 2(3), 164-167.

Matthews, G. (2016). Distress. Elsevier. 1 (26): 219. http://dx.doi.org/10.1016/B978-012-800951-2.00026-1. [Accessed on July 20, 2017].

Nurhadi \& Nursalam. (2003). Effect of Spiritual Guidance on Response Admissions in Patients Terminal. Unpublished thesis. PSIK-Medical Faculty Airlangga University Surabaya.

Nursalam. (2008). Concept and Application of Nursing Research Methodology. Jakarta: Salemba Medika.

Paul, G., Elam, B., \& Verhulst, S. J. (2007). A longitudinal study of students' perceptions of using deep breathing meditation to reduce testing stresses. Teaching and Learning in Medicine: An International Journal, 19(3), 287-292. doi: 10.1080/10401330701366754. https://ww w.ncbi.nlm.nih.gov/ pubmed/17594225. 
Kushariyadi: Nursing Modality Therapy (Spiritual Deep Breathing) Resolve Student Distress

Potter \& Perry, A. G. (2006). Textbook Fundamentals of Nursing: Concepts, Process, and Practice ( $4^{\text {th }}$ Ed., vol.2). Jakarta: EGC.

Saam, Z. (2006). Causes of Stress. Faculty of Medicine of Riau. Peenelitian report of Riau.

Sepdianto, C. (2008). Effects of Slow Deep Breathing Exercises Against Blood Pressure and Hypertension Patients Anxiety Levels in Kota Blitar. Thesis. Depok: Post Graduate Program Faculty of Nursing, University of Indonesia.

Shannon, H. S., \& Rosenbloom, J. B. D. (1999). Predictor of Psychological distress in the Work Place. Study. CHEPA working paper series.

Sherina, M. S., Rampal, L., \& Kaneson, N.
(2004). Medical psychological stress among undergraduate students. Med J Malaysia, 59, 207-11.

Valentina, P., \& Blandini, M. (2016). The role of deep breathing on stress. Original Article. Springer-Verlag Italia. Neurol Sci, doi: 10.1007/s10072-016-2790-8.

Wahyuni, S. (2015). Knowledge level relationships with students experiencing anxiety typhus in Jember University Health Services Unit. Jember: Jember University

Winkler, M. F., Malone, A. M., Mahan, L. K., \& Escort, S. S. (2008). Medical nutrition therapy for metabolic stress: sepsis, trauma, burns, and surgery. Krause's Food and Nutrition therapy, Elsevier: 1021-1041. 